\title{
СОВРЕМЕННЫЕ ТЕНДЕНЦИИ ДЕНЕЖНЫХ ПЕРЕВОДОВ МИГРАНТОВ В РОССИИ И В МИРЕ *
}

\author{
МИХАИЛ ДЕНИСЕНКО, ВЛАДИМИР КОЗЛОВ, АСИЯ ФАТТАХОВА
}

\begin{abstract}
В статье описаны глобальные тенденции денежных переводов, факторы, влияющие на них. Авторы рассматривают происходившие за последнее время изменения среди стран-лидеров в области передачи и получения денежных переводов и анализируют причины данных изменений. Кроме того, отдельно освещаются вопросы значимости потоков денежных переводов для сочиальноэкономического положения бедных стран. Статья открывается анализом источников данных о денежных переводах, поскольку в этой области статистики за последнее время произошли существенные концептуальные изменения. Особое внимание авторов посвящено денежным переводам в Россию, а также причинам расхождений между объемами денежных переводов в нашей стране, рассчитанных по методологии ЦБ и источников Мирового Банка.
\end{abstract}

Ключевые слова: денежные переводы, миграчия, переводы мигрантов и развитие.

Рубеж XX-XXI веков ознаменовался утверждением для глобальной экономики в целом, и экономик отдельных стран развивающегося мира, в частности нового мощного фактора развития - переводов (трансфертов) международных мигрантов. По оценкам Всемирного банка, в 1990 г. объем полученных переводов в денежной форме равнялся 64 млрд долл., в 2000 г. - 127 млрд, а в 2014 г. - 593 млрд. Примерно в 30 странах мира в 2014 г. денежные переводы составляли более $10 \%$ от валового внутреннего продукта (ВВП) или приближалась к этому порогу [World Bank Group 2015]. Среди этих стран - Таджикистан, Киргизия, Молдавия, Армения, Грузия, Узбекистан, Филиппины, Босния и Герцеговина, Черногория, Шри-Ланка, Бангладеш. Такому бурному росту способствовали, во-первых, заметное увеличение потоков трудовой, а также других форм миграции, во-вторых, развитие международных финансовых институтов, сопровождающееся распространением формальных каналов и удешевлением денежных переводов, в-третьих, становление и улучшение качества учета международных денежных переводов.

МИХАИЛ БОРИСОВИЧ ДЕНИСЕНКО. ИНСТИТУТ ДЕМОГРАФИИ НАЦИОНАЛЬНОГО ИССЛЕДОВАТЕЛЬСКОГО УНИВЕРСИТЕТА «ВЫСШАЯ ШКОЛА ЭКОНОМИКИ», РОССИЯ. E-mail: mdenissenko@hse.ru

ВЛАДИМИР АЛЕКСАНДРОВИЧ КОЗЛОВ. ИНСТИТУТ ДЕМОГРАФИИ НАЦИОНАЛЬНОГО ИССЛЕДОВАТЕЛЬСКОГО УНИВЕРСИТЕТА «ВЫСШАЯ ШКОЛА ЭКОНОМИКИ», РОССИЯ.

АСИЯ АСФАНОВНА ФАТТАХОВА. ИНСТИТУТ ДЕМОГРАФИИ НАЦИОНАЛЬНОГО ИССЛЕДОВАТЕЛЬСКОГО УНИВЕРСИТЕТА «ВЫСШАЯ ШКОЛА ЭКОНОМИКИ», РОССИЯ.

СТАТЬЯ ПОСТУПИЛА В РЕДАКЦИЮ В МАРТЕ 2015 Г.

* СТАТЬЯ ПОДГОТОВЛЕНА ПО РЕЗУЛЬТАТАМ ПРОЕКТА ПРОГРАММЫ ФУНДАМЕНТАЛЬНЫХ ИССЛЕДОВАНИЙ НИУ ВШЭ «СОВЕРШЕНСТВОВАНИЕ МЕХАНИЗМОВ ПРИВЛЕЧЕНИЯ И ИСПОЛЬЗОВАНИЯ ИНОСТРАННЫХ РАБОТНИКОВ В РОССИЙСКОЙ ФЕДЕРАЦИИ» (2015 Г., ТЗ-114) 
Тема трансфертов международных мигрантов новая для России и других бывших союзных республик. Информации об этом явлении не было до середины 1990-х годов. Но ситуация кардинально изменилась в 2000-х годах [Глущенко 2005]. Россия быстро вошла в тройку лидеров стран-источников переводов (вместе с США и Саудовской Аравией), а половина бывших союзных республик - в число лидеров по объемам полученных денежных переводов или их отношению к ВВП этих стран. Денежные переводы мигрантов в России и мире за последние годы - главная тема этой статьи. Авторы специально остановились на вопросах значимости этих потоков для социально-экономического положения бедных стран. Статья открывается анализом источников данных о денежных переводах, поскольку в этой области статистики за последнее время произошли существенные концептуальные изменения.

\section{СЛОЖНОСТИ УЧЕТА ПЕРЕВОДОВ МИГРАНТОВ}

В научных работах при всем различии в подходах переводы мигрантов определяются как передача части средств, обычно в денежной, но возможно и в натуральной форме, заработанных мигрантами за рубежом, их родственникам и друзьям на родине [IMF, Eurostat, OECD, World Bank 2009]. Однако использовать на практике это определение для организации качественного статистического наблюдения за переводами мигрантов нелегко. Во-первых, как известно, нет единства в понятии «мигрант». В различных странах для его определения используются разные пространственно-временные и социальные критерии. Во-вторых, существуют объективные трудности выделения связанных с международной миграцией потоков между домохозяйствами в денежной и неденежной форме. Как учитывать расходы мигрантов в стране пребывания? Как быть с получением подарков от друзей или родственников, всегда проживавших за рубежом, с покупкой товаров через них или с погашением задолженности перед ними? Как учитывать потоки, идущие по неформальным каналам? Как оценить потоки в неденежной форме?

Существует несколько источников информации о денежных переводах, и каждый из них имеет свои достоинства и недостатки, а также выполняет свою эвристическую функцию [Денисенко, Хараева 2008]. Среди них выделяют международные системы учета денежных переводов, отчетность операторов денежных переводов, обследования домашних хозяйств и косвенные оценки, выполняемые на основе привлечения разнообразных данных с применением математических моделей.

Международные системы учета денежных переводов основаны на отчетности банков и иных финансовых институтов об индивидуальных международных переводах (транзакциях), а также о финансовых операциях нерезидентов. К этому источнику примыкает прямая отчетность операторов денежных переводов. Большим преимуществом этих источников является низкая стоимость получения данных практически за любой промежуток времени. Они используются для построения платежного баланса страны. Вместе с тем остаются неохваченными другие каналы денежных переводов и переводов в материальной форме. Кроме того, получаемые оценки зависят от пороговой суммы для переводов, которая устанавливается для банковской отчетности. 
Таким образом, оценки, получаемые на основе отчетности банков и операторов денежных переводов, - это оценки обусловленных международной миграцией финансовых потоков в стране или между странами. Но эти источники информации не являются идеальными. Они не позволяют определить объемы переводов в неденежной форме, выявить особенности «трансфертного» поведения отдельных категорий мигрантов (например, индивидуальных предпринимателей), установить цели, на которые расходуются полученные их родственниками средства, оценить роль разных формальных и неформальных каналов в осуществлении переводов и др. Ответы на эти вопросы получают с помощью обследований домохозяйств. Во многих странах соответствующие блоки вопросов включаются в регулярные обследования, например, в обследования бюджетов домашних хозяйств или обследования рабочей силы. В тех странах, где миграция и денежные переводы имеют большое экономическое значение, проводятся специальные обследования мигрантов. Среди этих стран можно назвать и страны СНГ: Киргизию, Таджикистан, Молдавию, Армению. Несомненно, обследования как источник данных обладают большой информативностью, позволяют контролировать сбор и качество данных. Но высокие издержки препятствуют их частому проведению, а на качестве результатов может сказаться искажение информации респондентами, прежде всего из-за давности изучаемых событий. Тем не менее в странах, где развита система выборочных обследований (например, в США), они служат основным источником информации о переводах мигрантов.

Данные о переводах мигрантов получают также непрямыми (косвенными) методами на основе дополнительной информации (например, демографической) с помощью демографических или эконометрических моделей [Shelburne, Palacin 2007] или методом закрытия баланса всех международных финансовых обменов. Предполагается, что полученные остатки относятся к денежным переводам мигрантов. С помощью этих подходов можно рассчитать и отдельные компоненты переводов мигрантов. Но применение косвенных методов должно основываться на надежных данных, прежде всего о численности мигрантов. Здесь сразу возникает вопрос, как быть с незаконными мигрантами? Включать или не включать их в расчеты? Кроме того, константы, полученные в уравнениях модели за предыдущие годы, могут не подойти для оценок текущего года.

Остановимся подробней на природе показателей переводов мигрантов, которые используются в мировой практике. С целью сопоставимости данных и повышения их качества эти показатели разрабатываются специальной рабочей группой, в которую входят представители международных организаций и ряда национальных финансовых институтов, ${ }^{1}$ в рамках концепции платежного баланса страны.

До 2008 г. в большинстве стран мира официальным источником информации о трансграничных денежных переводах физических лиц служили данные, собираемые

\footnotetext{
1 В числе этих организаций: Международный валютный фонд, Всемирный банк, Организация по экономическому сотрудничеству и развитию (OECD), Евростат. В 2009 г. по инициативе G8 была создана Global Remittances Working Group (GRWG) для координации международных инициатив и оказания технической помощи национальным финансовым институтам и международным организациям в области переводов мигрантов. В эту группу входят представители Банка России.
} 
Центральными банками разных стран по пятой методологии ВОР5² построения платежного баланса, разработанной в 1993 г. Международным валютным фондом [IMF 1993]. Согласно этой методологии, денежные переводы мигрантов складываются из трех компонентов платежного баланса страны (таблица 1).

Таблица 1. Денежные переводы мигрантов и их компоненты по методологии ВОР5

\begin{tabular}{l|l}
\hline Компонента & \multicolumn{1}{c}{ Определение } \\
\hline & Начисленная заработная плата и другие платежи (в том числе в \\
Оплата труда работников & натуральной форме), получаемые сезонными, приграничными и \\
(compensation of employees) & $\begin{array}{l}\text { временными работниками-нерезидентами, прибывшими в } \\
\text { принимающую страну на срок менее одного года (учитывается в } \\
\text { счете «Доходы от инвестиций и оплата труда») }\end{array}$ \\
Денежные переводы работников & Денежные переводы иностранных граждан, проживающих в другой \\
(workers' remittances) & стране более года (учитываются в счете «Текущие трансферты») \\
Tрансферты, связанные с & Стоимость имущества и финансовых активов, сопровождаюих \\
миграцией населения (migrants' & мигрантов при переезде в другую страну (учитываются в статье \\
transfers) & «Капитальные трансферты») \\
\hline
\end{tabular}

Источник: [IMF 1993].

Методология ВОР5 по мере роста объемов денежных переводов и интереса к связанным с ними проблемам стала конструктивно пересматриваться в 2000-х годов. По мнению многих экспертов, фактически переводы мигрантов, определяемые по этой методологии, не соответствовали их определению [Денисенко, Хараева 2008]. В частности, показатель денежных переводов работников, полученный из платежного баланса, не отражал объема фактически выполненных трансфертов, поскольку в нем учитывалась вся заработная плата, начисленная иностранным гражданам, без исключения из нее налогов и потребленных на месте товаров и услуг.

В 2008 г. Международный валютный фонд предпринял шестое издание «Руководства по платежному балансу и международной инвестиционной позиции» (BОР6) [IMF 2009]. В России платежный баланс по новой методологии начали составлять с 2012 г. Изменения в ВОР6 включают: 1) переход к четырем новым категориям, относящимся к денежным переводам; 2) отказ от использования понятия «мигрант» в пользу понятий «место проживания», «резидент», «нерезидент»; 3) устранение из определения денежных переводов «трансфертов, связанных с миграцией»; 4) указание для денежных переводов стран их назначения и происхождения. Решение о выделении в статистике платежных балансов потоков денежных переводов между парами стран направлено на улучшение полноты и качества их статистики, разрешение противоречий между учетными системами денежных переводов взаимодействующих в миграционном отношении стран.

Основным измерителем денежных переводов мигрантов стал показатель «Личные переводы» (“Personal Remittances"). Он определяется как текущие и капитальные трансграничные трансферты в денежной и неденежной форме между домохозяйствами резидентов и нерезидентов плюс «чистая оплата труда» иностранных работников [IMF, Eurostat, OECD, World Bank 2009].

${ }^{2}$ BOP - Balance of Payment. 
Категория «Оплата труда работников» в ВОР6 соответствует той, которая использовалась в ВОР5. Но в оценку «Личных переводов» включается только та ее часть, которая может передаваться нерезидентом на родину, т.е. чистая оплата труда, представляющая собой заработок иностранного работника без учета налогов, расходов на проживание и питание, транспортных расходов, социальных платежей (взносов).

От концепции «денежных переводов работников» («workers' remittances») было решено перейти к концепции «личных трансфертов» («personal transfers»). К «личным трансфертам» относятся все текущие трансграничные трансферты в денежной и неденежной форме между резидентами и нерезидентами. В отличие от «переводов работников» концепция «личных трансфертов» не связана непосредственно с определениями миграции или занятости, что позволяет избежать целого ряда внутренних концептуальных противоречий ВОР5.

Также выделяется третья составляющая «Капитальные трансферты между домохозяйствами». К ним относятся случаи передачи имущества, собственности, прощения долга. Но количественную оценку этой компоненты трудно получить, и в большинстве стран мира она не оценивается. В России эта составляющая включается в состав «личных трансфертов».

Величина другой новой категории «Общие переводы» (“Total Remittances”) равна объему «Личных переводов» с учетом социальных пособий, включающих пенсии, пособия по безработице, на детей и др. Кроме того, отдельно выделяют переводы некоммерческих организаций (НКО), обслуживающих домашние хозяйства мигрантов (социальные службы, грантодатели, музеи, медицинские учреждения, образовательные учреждения, профсоюзы и др.).

Таблица 2. Денежные переводы мигрантов и их компоненты по методологии ВОР6

\begin{tabular}{|c|c|c|c|c|c|}
\hline \multicolumn{6}{|c|}{ Общие переводы и переводы в НКО } \\
\hline \multicolumn{4}{|c|}{ Общие переводы } & \multirow{3}{*}{$\begin{array}{c}\text { Текущие } \\
\text { трансферты в } \\
\text { НКО }\end{array}$} & \multirow{3}{*}{$\begin{array}{c}\text { Капитальные } \\
\text { трансферты в } \\
\text { НКО }\end{array}$} \\
\hline \multicolumn{3}{|c|}{ Личные переводы } & \multirow{2}{*}{$\begin{array}{c}\text { Социальные } \\
\text { пособия }\end{array}$} & & \\
\hline $\begin{array}{c}\text { Личные } \\
\text { трансферты }\end{array}$ & $\begin{array}{c}\text { Оплата труда без } \\
\text { налогов, } \\
\text { социальных } \\
\text { платежей, } \\
\text { расходов на } \\
\text { проживание и пр. }\end{array}$ & $\begin{array}{c}\text { Капитальные } \\
\text { трансферты между } \\
\text { домохозяйствами }\end{array}$ & & & \\
\hline
\end{tabular}

Источник: [IMF, Eurostat, OECD, World Bank 2009].

В России информационной базой для исчисления «личных переводов» служат отчеты о трансграничных операциях физических лиц, выполняемых банками и операторами денежных переводов (Отчетность по форме 0409407 «Сведения о трансграничных переводах физических лиц») в Центральный банк Российской Федерации [ЦБ РФ 2014а]. В состав личных переводов не включаются: переводы, связанные с инвестициями в иностранные активы (в том числе покупка недвижимости); переводы средств в части доходов от оказания услуг; переводы в пользу граждан, находящихся за рубежом с целью туризма, лечения или обучения; переводы для оплаты товаров и услуг. При этом в состав «личных переводов» включаются «некрупные переводы» между 
резидентами и нерезидентами или между резидентами одной экономики (часть чистой оплаты труда).

Следует заметить, что переход на новую методологию (ВОР6) исчисления платежного баланса и определения переводов мигрантов происходит в странах мира неравномерно. При сопоставлении национальных оценок денежных переводов необходимо обращать внимание на то, как исчислялся показатель «оплаты труда»: с учетом или без учета разного рода выплат. Из-за разных методик исчисления этого показателя национальные данные могут не совпадать с оценками ведущих международных экспертов, представленных в изданиях Всемирного банка, МВФ или ОЭСР. Так, по оценкам в недавно опубликованном авторитетном справочнике «Migration and Remittances. Factbook 2016» [World Bank Group 2015], в 2013 г. объем отправленных из России переводов мигрантов составил 3,72 млрд долл., а поступивших в Россию - 6,8 млрд. По данным ЦБ РФ, в указанном году в Россию поступило 6,4 млрд долл., а было отправлено 30,4 млрд. Причина разницы в оценках кроется в том, что международные эксперты использовали показатель «оплата труда работников» без социальных вычетов и расходов на проживание, т.е. по методологии ВОР5. Вероятно, это сделано в целях унификации подхода к оценке компонент переводов мигрантов, поскольку не для всех стран можно определить «чистую оплату труда». ЦБ РФ рассчитывает именно «чистую оплату труда», т.е. из оплаты труда иностранных работников вычитаются подоходные налоги, взносы в пенсионный фонд, транспортные (обратный билет) и другие расходы. Вместе с тем важно знать, что расчеты ЦБ РФ опираются на информацию: 1) о численности иностранных работников на территории Российской Федерации, а также о численности и составе российских граждан, выехавших на работу за границу; 2) о средней заработной плате по видам экономической деятельности за вычетом расходов на пребывание. От точности этой информации, собираемой ФМС России и Росстатом, зависит точность оценок компоненты «чистая оплата труда», а следовательно и всего объема переводов мигрантов.

\section{ГЛОБАЛЬНЫЕ ТЕНДЕНЦИИ ДЕНЕЖНЫХ ПЕРЕВОДОВ}

Объем переводов мигрантов увеличивается по экспоненте (рисунок 1). За десять предшествующих лет объемы переводов возросли к 1990 г. в 1,6 раза, к 2000 г. в 2 раза, к 2010 г. в 3,6 раза. По уточненной оценке Всемирного банка [World Bank Group 2015], в 2014 г. совокупный объем учтенных полученных денежных переводов составил 592 млрд долларов США против 572 млрд в 2013 г. и 463 млрд в 2010 г. В 2015 г., по предварительной оценке, сумма денежных переводов международных мигрантов превысила 600 млрд долларов США³ повлиял на объемы денежных переводов очень незначительно.

Основной объем денежных переводов мигрантов направляется из развитых в развивающиеся страны, к которым Всемирный банк относит страны со средним и низким

3 Здесь приведены официально учтенные суммы денежных переводов. Истинный размер учтенных и неучтенных денежных переводов, совершаемых через официальные и неофициальные каналы, за счет стран, в которых стоимость переводов высока, возможно, превосходит официальные в 1,5 раза или даже больше. 
уровнем валового национального дохода на душу населения. В совокупном объеме денежных переводов мигрантов доля развивающихся стран быстро возрастает: в 1990 г. она составляла около 45\%, в начале 2000 -х годов - уже 65\%, а в 2012-2014 гг. - около 75\%. Совокупный объем учтенных денежных переводов в развивающиеся страны составил в 2012 г. 400 млрд долларов США, в 2013 г. 416 млрд, а в 2014 г. 431 млрд. По оценкам экспертов Мирового банка, эта величина в 2015 г. составит порядка 435 млрд [World Bank 2015]. Ожидалось, что в 2015 г. прирост переводов мигрантов снизится за счет стран региона Европы и Центральной Азии. Однако предварительные данные показывают, что явного снижения не произошло.

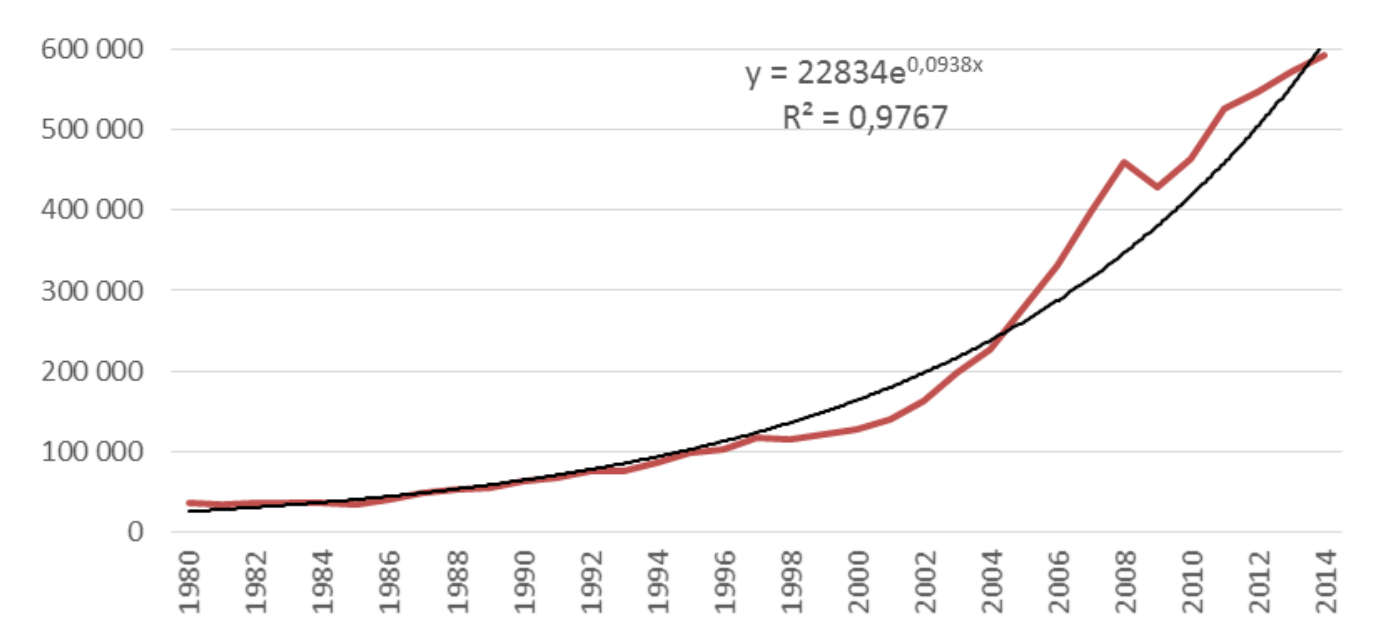

Рисунок 1. Совокупный объем полученных денежных переводов в мире, 1980-2014, млн долларов США

Источник: [World Bank Data 2016; World Bank Group 2015].

Существенное влияние на величину и распределение денежных переводов (данные причины справедливы в основном и для потоков международной миграции, особенно трудовой) в 2014-2015 гг. оказывали следующие четыре фактора:

1. неравномерное восстановление экономического роста в развитых странах (например, быстрое восстановление в США и Великобритании и более медленное - по сути начавшееся только в 2015 г. - в континентальной Европе);

2. падение цен на нефть и укрепление доллара по отношению к некоторым национальным валютам, ведущее к снижению доходов в нефтедобывающих странах и, как следствие, уменьшению притока трудовых мигрантов;

3. усиление иммиграционного контроля в странах, из которых отправляются значительные объемы денежных переводов мигрантов;

4. конфликты, приводящие к формированию потоков вынужденной миграции.

Остановимся на этих факторах подробнее. Значительное укрепление экономики США явилось стимулом для увеличения объема денежных переводов, отправляемых из страны. С ростом строительства и занятости в сфере услуг, включая гостиничный и ресторанный сектор, возросли объемы денежных переводов в Мексику, Сальвадор, Гватемалу, Гондурас и Никарагуа. Потоки в страны Латинской Америки могли быть и больше, если бы некоторые из них не испытали влияние экономического спада и высокой 
безработицы в Испании (объем денежных переводов из Испании в 2014 г. был ниже даже уровня 2006 г. $^{4}$ ). Слабый и неоднородный экономический подъем в странах Еврозоны препятствовал сильному росту денежных потоков из этого региона (в лидерах - Франции, Люксембурге и Нидерландах - наблюдался спад или стагнация потоков, в Германии рост был довольно незначительным). В результате замедлился рост денежных переводов в страны Магриба, для которых Европа - основной источник денежных переводов.

Снижение цен на нефть и введение экономических санкций, как будет показано дальше, оказали существенное негативное влияние на экономику России в 2014 г., а в результате и на экономику таких стран, как Армения, Молдавия, Киргизия, Узбекистан и Таджикистан, в значительной степени зависящих от денежных переводов из России. Кроме того, ослабление курса рубля по отношению к доллару США и валютам большинства стран СНГ привело к снижению покупательной способности денежных переводов из России, что заметно снизило уровень жизни бедных слоев населения в странах Средней Азии.

Но снижение цен на нефть пока не привело к уменьшению переводов мигрантов из государств Совета сотрудничества стран Персидского залива в Индию, Бангладеш, Непал, Пакистан, некоторые страны Ближнего Востока и Северной Африки. Значительные финансовые ресурсы и долгосрочные планы развития инфраструктуры будут способствовать сохранению спроса на рабочие руки мигрантов, однако при сохранении низких цен на нефть в течение нескольких лет объемы денежных переводов из региона могут сократиться.

Укрепление доллара США оказывает заметное влияние на стоимостную оценку денежных переводов. Так, объем денежных переводов из стран Европейского союза в Марокко в январе 2015 г. по сравнению с ноябрем 2014 г, рассчитанный в евро, увеличился на 9,6\%, а пересчитанный в доллары США, снизился на 2,3\%. Денежные переводы из России в Таджикистан в IV квартале 2014 г. по сравнению с тем же периодом 2013 г., рассчитанные в рублях, увеличились на 7,6\%, а в долларах США снизились на 26,7\%.

Введение в 2014 г. норм, ужесточающих ответственность за нарушение миграционного законодательства (запрет на въезд от 3 до 5 лет, а с 2015 г. - до 10 лет), а также введение новых правил на въезд из стран с безвизовым пересечением границы (ограничение срока пребывания без разрешительных документов в 90 дней одним разом за 180 дней) привели к значительному сокращению числа мигрантов в России. Усиление мер контроля на юго-западной границе США (увеличение числа патрулей, систем воздушного и наземного слежения) сдерживает число мигрантов, пересекающих границу со стороны Мексики, в том числе детей без сопровождения взрослых из стран Центральной Америки.

Правила иммиграции становятся строже и избирательней и в других частях света. В частности, сравнительно открытая иммиграционная политика Сингапура, вызывавшая протесты общественности, привела к увеличению численности международных мигрантов более чем на $31 \%$ за 2004-2014 гг. В соответствии с новыми правилами работодатели при

\footnotetext{
${ }^{4}$ Пиковыми годами для потоков денежных переводов из Испании (порядка 12,5 млрд долл.) были 2007 и 2008
} $\Gamma$. 
найме работников должны в первую очередь рассматривать кандидатуры из числа граждан Сингапура и лишь затем из числа иностранных граждан.

Европа также находится в поисках новой иммиграционной политики, способной сдержать нарастающие потоки мигрантов, прибывающих через Средиземное море. В 2014 г. в Европейский союз нелегально прибыло 283 тыс. человек, что более чем в 2 раза превышает поток в 2013 г. (107 тыс. человек). Почти 230 тыс. нелегальных мигрантов пересекли Средиземное море [European Parliament 2015].

Конфликты нарушают привычную мирную жизнь населения, порождая масштабные потоки беженцев и лиц, ищущих убежища. Регион Ближнего Востока и Северной Африки стал основным регионом исхода беженцев. Число беженцев из Сирии возросло до 3,9 млн человек к началу 2015 г., а к его концу превысило 4,5 млн (без учета внутренних мигрантов). Из них более 1 млн направились в 2015 г. в Европу. Еще ранее война в Ираке и последствия войны в Ливии вызвали усиление миграционного давления на Европу.

В результате конфликта на Украине, по данным УВКБ ООН на середину 2015 г., число внутренне перемещенных лиц составило около 1,4 млн человек, около 320 тыс. граждан страны обратились за убежищем, правом на проживание или другими формами легального пребывания в соседних странах (из них порядка 310 тыс. - в России) [UNHCR 2015].

Лидером по объему полученных денежных переводов являются в основном страны с большим оттоком мигрантов. Среди них выделяются Индия, Китай, Филиппины, Мексика. По предварительным оценкам, в 2015 г. список стран, в которые поступили наибольшие объемы денежных переводов мигрантов, возглавили Индия (72 млрд долларов США) и Китай (64 млрд), во многом благодаря большому числу трудовых мигрантов и многочисленным диаспорам. За ними следуют со значительным отрывом Филиппины (30 млрд), Мексика (26 млрд), Франция (25 млрд), Нигерия (21 млрд), Египет и Пакистан (по 20 млрд; рисунок 2). На них приходится 47\% всех мировых денежных переводов и более половины всех денежных переводов, направленных в развивающиеся страны.

Наряду с этим в группу стран - крупнейших получателей денежных переводов мигрантов входят и некоторые развитые страны. Кроме Франции, это Германия, Бельгия, Испания. Во многом такие объемы финансовых потоков являются результатом интенсивного миграционного обмена между развитыми странами, прежде всего, в ЕС. Однако будучи весомыми по своей абсолютной величине в глобальной сети денежных переводов, эти средства незначительны для данных стран по отношению к объему произведенного в них ВВП, составляя от 0,2 до $0,8 \%$ от ВВП и только в Бельгии более значимую величину $-2,2 \%$ от ВВП.

Развитые страны обществу более известны не как получатели денежных переводов мигрантов, а как их доноры. То, что они все же выступают и в роли получателей, указывает на то, что, как и в случае с миграцией, каждому потоку соответствует контрпоток. Эти потоки неравны друг другу, и различия между ними тем больше, чем больше различия в уровне социально-экономического развития между взаимодействующими странами. Россия не является в этом смысле исключением. В 2014 г. по оценкам Всемирного банка 
Россия занимала третье место в мире по объему отправленных из страны денежных переводов (33 млрд) и в то же время находилась на 16-м месте в мире по объему полученных переводов (7,9 млрд). Большая часть этих переводов поступала с Украины $(31 \%)$, из Казахстана (20\%), других стран СНГ и Грузии (21\%), из Германии (10\%) и США (4\%). Но эти оценки заставляют задуматься о том, насколько корректна интерпретация денежных переводов как исключительно переводов мигрантов.

В списке главных получателей денежных переводов в 2013 г. находилась Украина (10-е место). Однако по сравнению с 2013 г. в 2015 г. приток переводов мигрантов сократился более чем 1,5 раза из-за падения курса рубля и ухудшения российскоукраинских отношений. В 2014 г. более половины (52\%) всех переводов поступило из России, около 14\% - из других республик бывшего СССР (не считая страны Балтии), 7,8\% - из США, порядка 2\% - из Канады и Австралии, остальные - преимущественно из европейских стран.

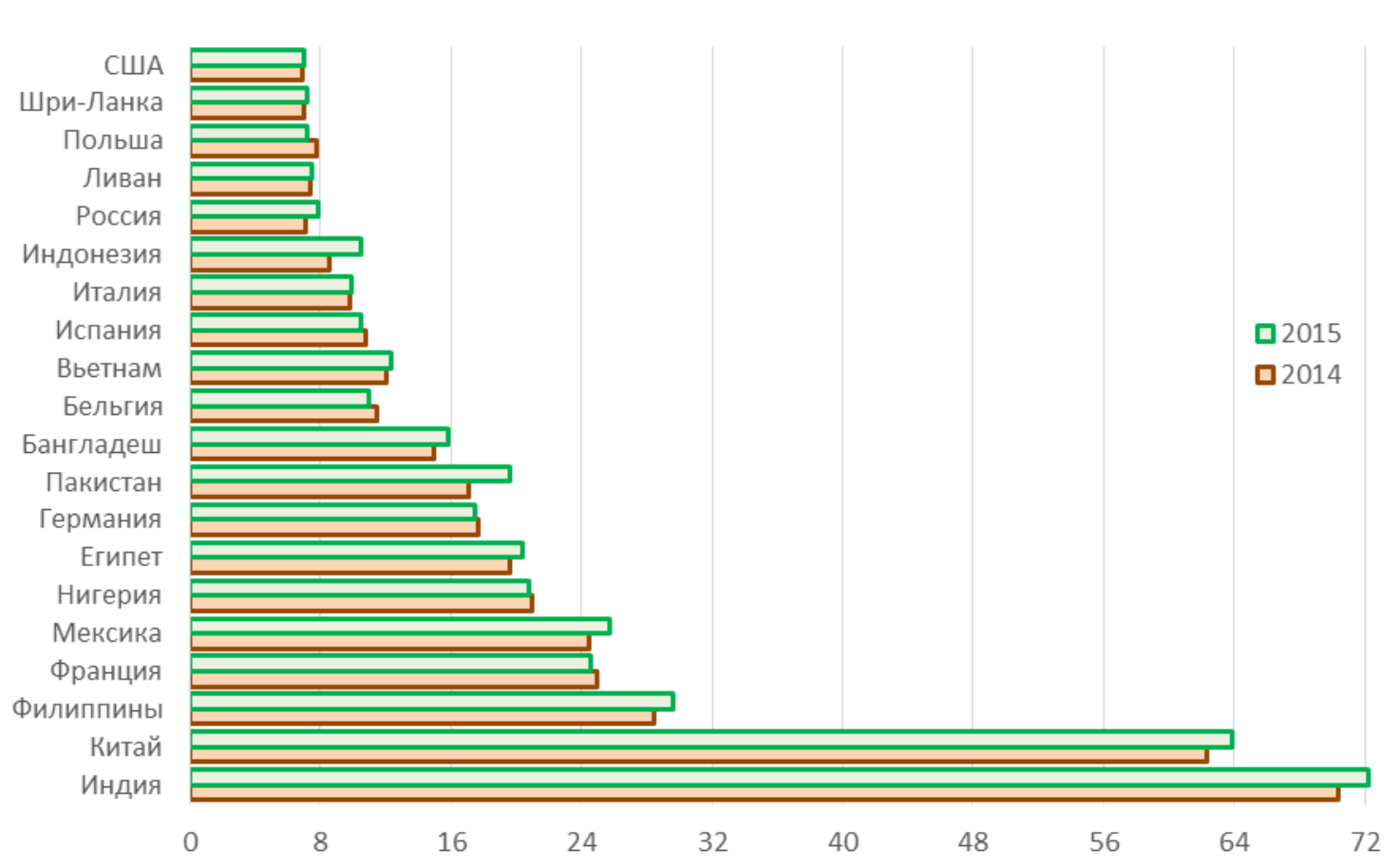

Рисунок 2. 20 стран - ведущих реципиентов денежных переводов мигрантов (объем получаемых трансфертов), 2014-2015, млн долларов США

Источник: [World Bank Group 2015].

Обращает на себя внимание тот факт, что в последние 10 лет список стран-лидеров не изменился существенным образом, однако темпы роста притока денежных переводов среди них были различными. Так, в Мексике наблюдалась стагнация, в Нигерии, Франции и Филиппинах умеренный, а в Индии и Китае быстрый рост (рисунок 3). 


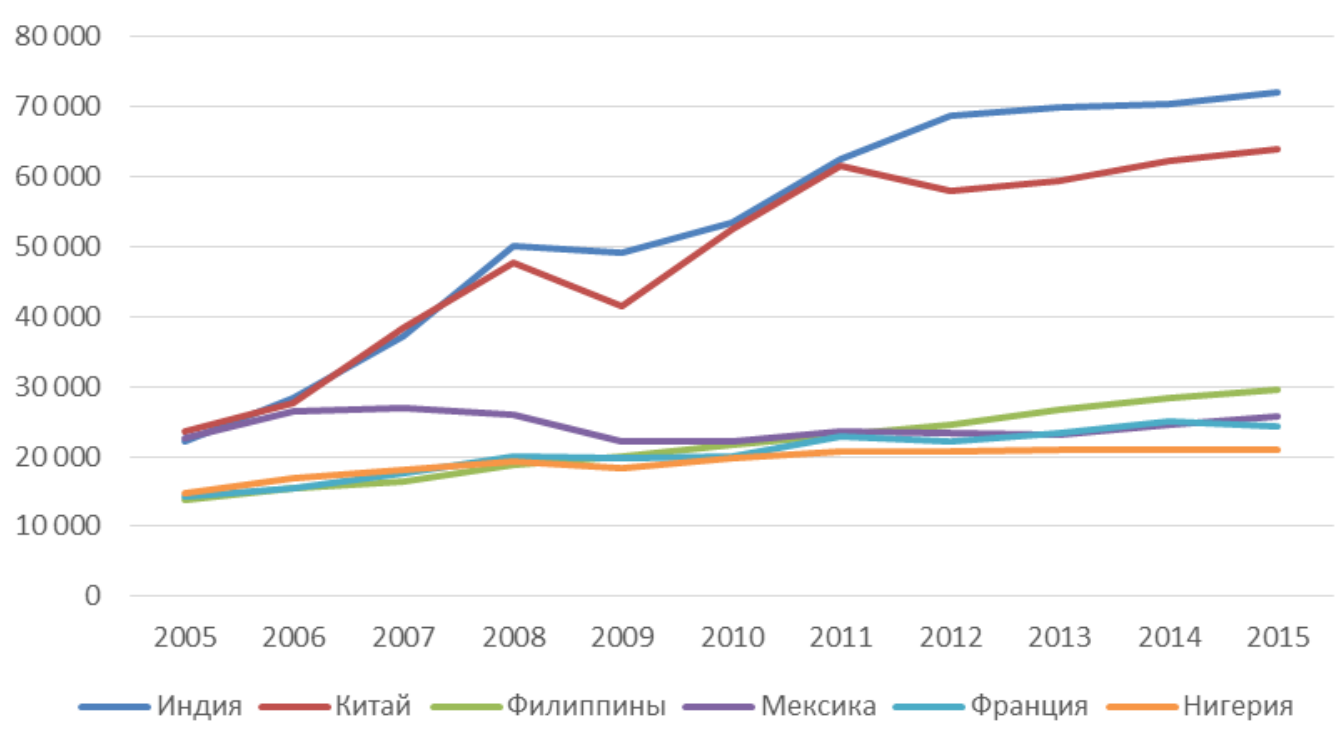

Рисунок 3. Денежные переводы мигрантов в ведущие страны-реципиенты, 2005-2015 гг., млн долларов США

Источник: [World Bank Data 2016; World Bank Group 2015].

В странах с низким уровнем экономического развития и небольшой экономикой объемы поступающих денежных переводов от мигрантов, напротив, составляют весьма существенную величину по сравнению с общим объемом ВВП (рисунок 4). Денежные переводы, направляемые мигрантами в Таджикистан, были эквивалентны почти половине производимого ВВП, в 2014 г. снизившись до уровня чуть выше 40\%, в Киргизии и Непале - около 30\%, в Тонго, Либерии и Молдавии - более четверти.

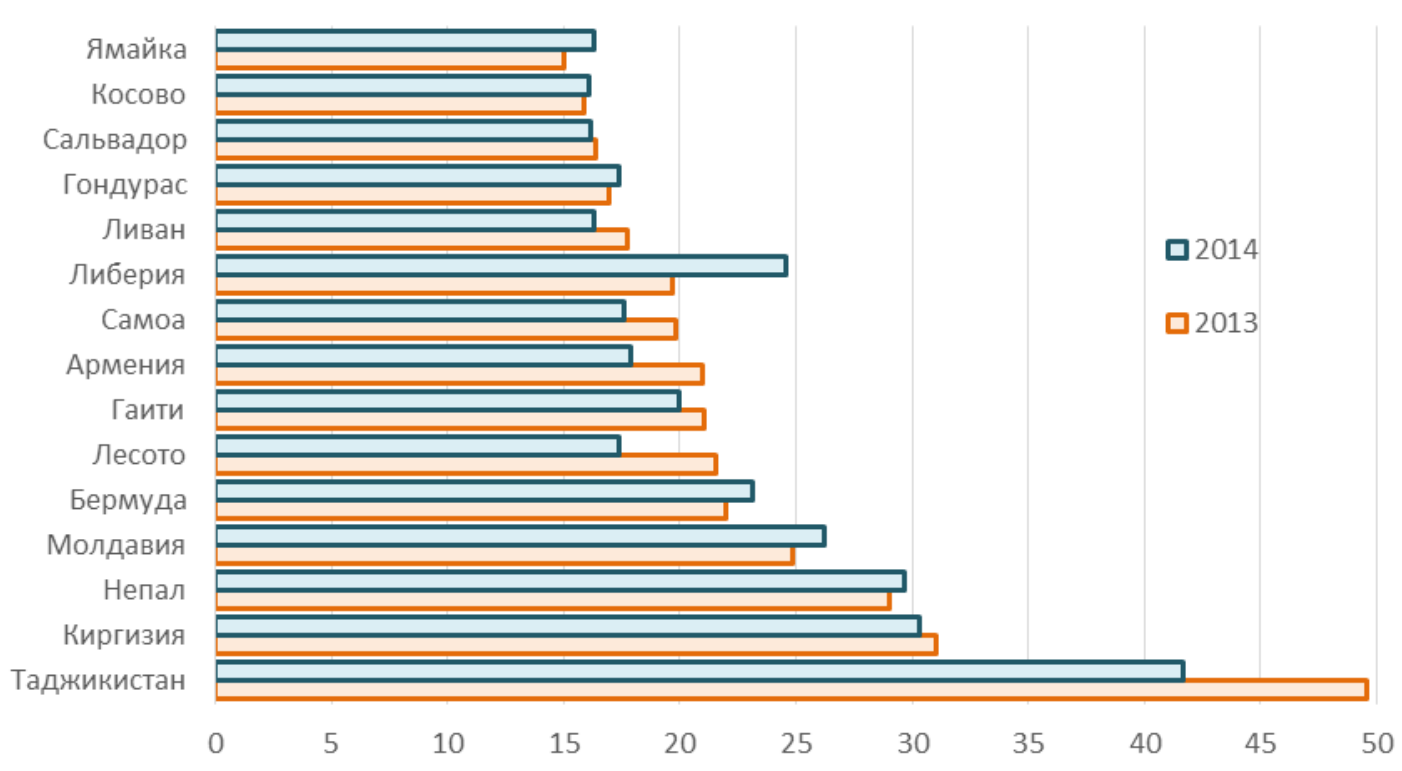

Рисунок 4. 15 стран с наибольшим относительным объемом полученных денежных переводов мигрантов, \% от ВВП соответствующих стран

Источник: [World Bank Group 2015]. 
Больше всего денежных переводов отправляется из США - в 2014 г. их общий объем превысил 56 млрд долл. (рисунок 5). На 2-е место после США в 2013 г. вышла России (почти 37 млрд долл.), за которой следовали Саудовская Аравия (35 млрд) и Швейцария (23 млрд). Однако в 2014 г. из Саудовской Аравии было отправлено 37 млрд долларов в виде переводов, а из России - 33 млрд. К числу крупнейших поставщиков денежных трансфертов мигрантов относятся также ОАЭ, Кувейт и Германия, за ними следуют Франция, Люксембург, Катар, Нидерланды и Южная Корея (рисунок 5).

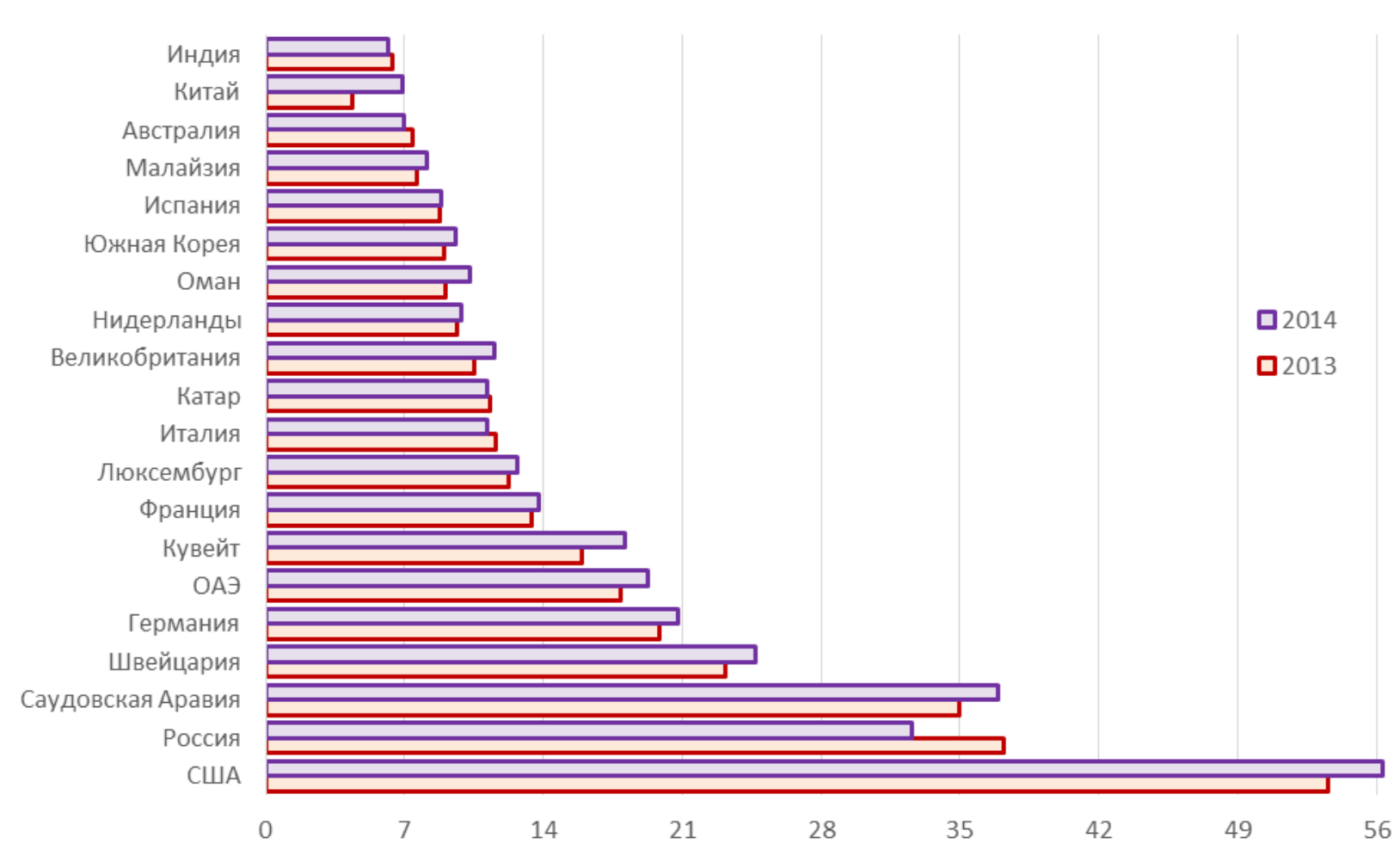

\section{Рисунок 5. 20 стран - ведущих доноров денежных переводов мигрантов (объем исходящих трансфертов), млн долларов США}

Источник: [World Bank Group 2015].

Позиция США как основной страны-донора выглядит устойчивой. Определенные колебания в потоках были обусловлены кризисом 2008 г. (рисунок 6). Во всех странах, входящих в шестерку лидеров, в последние годы исходящие денежные переводы в целом росли.

Наиболее динамично ситуация с переводами мигрантов меняется в России (колебания, вызванные изменением курса рубля и экономической ситуации) и Саудовской Аравии (быстрый устойчивый рост). Довольно быстрый для мира рост (более чем в 3 раза за последние пять лет) демонстрируют другие страны Персидского залива (Катар, Кувейт, Оман).

Основным реципиентом средств из США является Мексика, а остальные страны Латинской Америки отстают от стран-лидеров по получению трансфертов - Китая, Индии, Филиппин, Вьетнама и Нигерии (рисунок 7). 


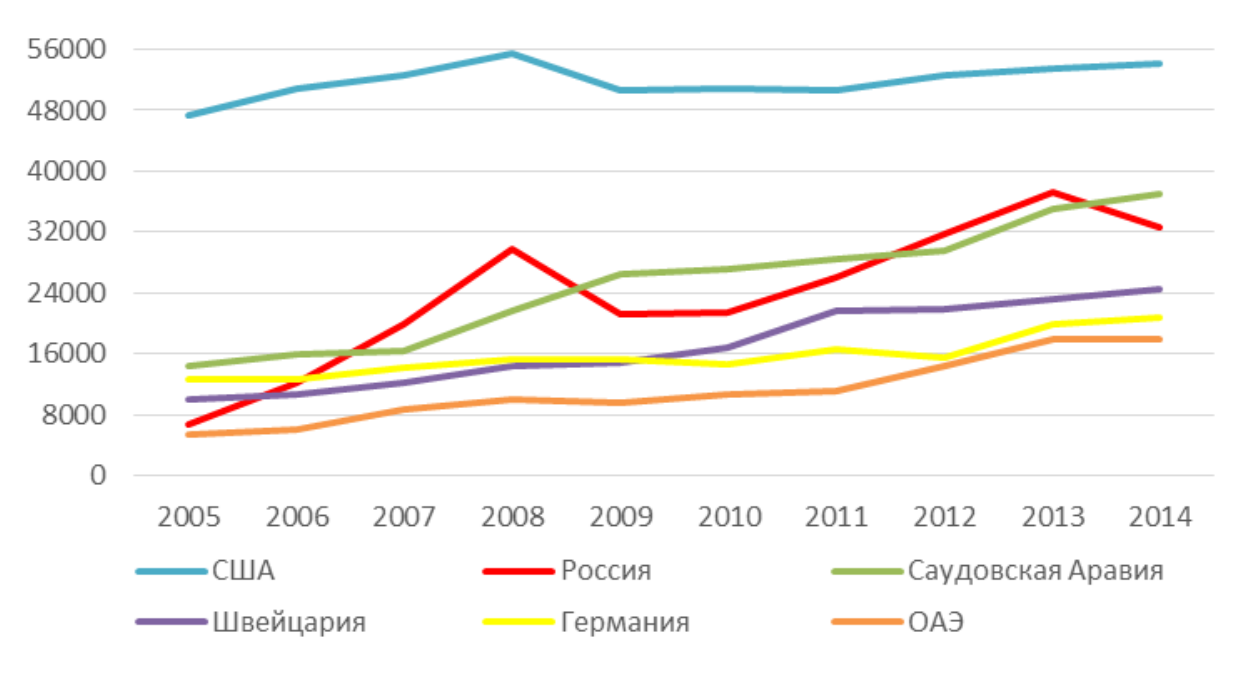

Рисунок 6. Денежные переводы мигрантов из ведущих стран-доноров, 2005-2014 гг. млн долларов США

Источник: [World Bank Data 2016; World Bank Group 2015].

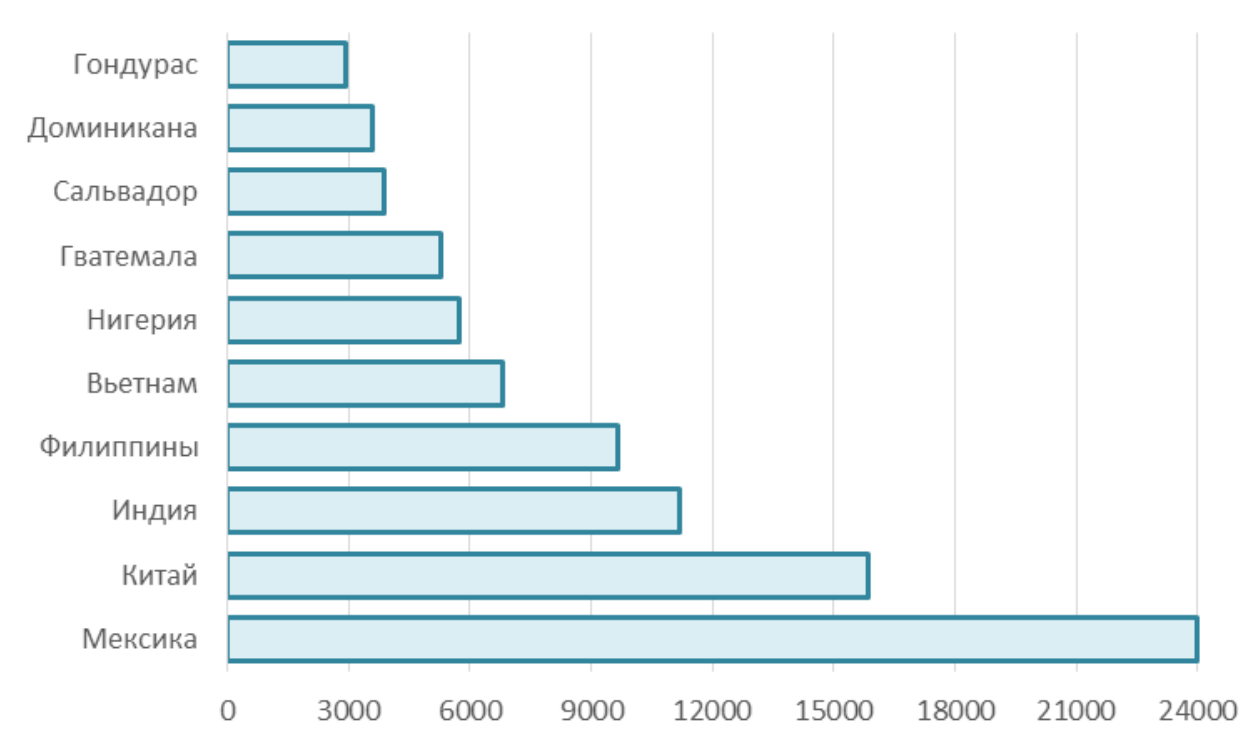

\section{Рисунок 7. Основные страны-получатели переводов мигрантов из США, 2014, млн долларов США}

Источник: [World Bank Group 2015].

Основной получатель средств из Саудовской Аравии - Индия, затем следуют Египет и крупнейшие мусульманские страны Азии: Пакистан, Бангладеш, Индонезия (рисунок 8).

Основные получатели переводов из России - страны СНГ. По оценкам Всемирного банка, в 2014 г. в эти страны было переведено более 19,3 млрд долл., в том числе: 5,6 млрд - в Узбекистан, около 4 млрд - в Украину, около 3 млрд - в Таджикистан, 1,7 млрд Киргизию, 1,4 млрд - в Армению, 1,2 млрд - в Грузию, 1,1 млрд - в Азербайджан, 0,7 млрд - в Молдавию.

Детально денежные переводы мигрантов в России рассмотрены ниже. 


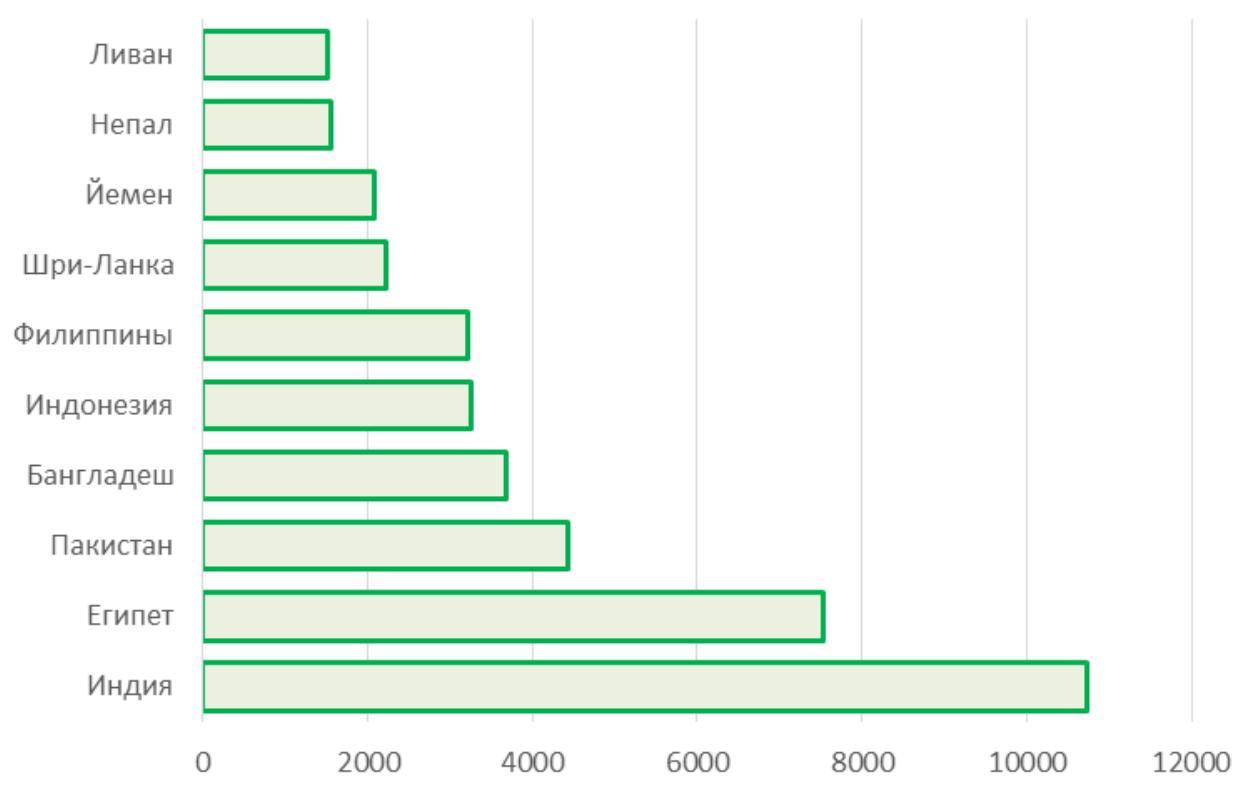

\section{Рисунок 8. Основные страны-получатели переводов мигрантов из Саудовской Аравии, 2014, млн долларов США}

Источник: [World Bank Group 2015].

Одним из факторов, определяющих объемы переводимых мигрантам средств по формальным и неформальным каналам в денежной и неденежной форме, является стоимость переводов. В 2009 г. на встрече руководителей государств «Группы восьми» в Аквиле (Италия) была поставлена задача снижения среднемировой стоимости денежных переводов с 10 до 5\% в 2014 г. ${ }^{5}$ По расчетам экспертов, это позволило бы оставить мигрантам и их семьям как минимум 16 млрд долл. в год. В 2010 г. цель по снижению стоимости переводов была поставлена на встрече руководителей стран двадцатки. В Целях тысячелетия была поставлена задача уменьшить стоимость переводов мигрантов до 3\% и устранить коридоры переводов со стоимостью переводов более 5\% [UN 2014].

Однако, несмотря на усилия международного сообщества, в 2014-2015 г. среднемировая стоимость денежных переводов стабилизировалась на уровне 8\%. При этом наблюдаются значительные региональные различия в их стоимости. Так, самая низкая стоимость зафиксирована для переводов мигрантов из Саудовской Аравии в Непал $(0,6 \%)$, из России в страны СНГ (от 1,1 до 1,7\%), из ОАЭ в Пакистан (1,7\%). Высокой стоимостью отличаются денежные переводы в беднейшие страны Африки (до 20\%), из Японии в Китай, Индию и Бразилию (от 14 до16\%), переводы в Китай и некоторые страны Азии из ряда развитых стран (от 12 до14\%).

В связи с появлением возможности совершения финансовых операций с помощью Интернета и мобильной связи сфера услуг денежных переводов переживает некоторые позитивные структурные изменения. Однако распространение этих новшеств не сказывается на цене переводов из-за недостаточной ясности правового регулирования их

\footnotetext{
5 Стоимость перевода определяется как отношение суммы всех сборов, включая потери из-за обменных курсов перевода, от перевода 200 долларов США к общей сумме перевода, выраженное в процентах.
} 
использования и в связи с мерами, направленными банками против «отмывания» денег, полученных незаконным путем, финансирования террористической деятельности и других финансовых преступлений [World Bank 2013]. Учитывая большое значение денежных переводов для экономики многих развивающихся стран, снижение их стоимости попрежнему остается в повестке дня мирового сообщества.

\section{ДЕНЕЖНЫЕ ПЕРЕВОДЫ И ЭКОНОМИКА СТРАН-ПОЛУЧАТЕЛЕЙ}

В теории и на практике денежные переводы рассматриваются в качестве важнейшего элемента, связывающего международную миграцию и экономику [Глущенко 2004; World Bank 2006; Chami et al. 2008; Catrinecsu et al. 2009]. Масштабы переводов мигрантов, как мы видели, во многих развивающихся странах настолько велики, что их влияние на развитие этих стран не подвергается сомнению. По словам одного из ведущих экономистов Всемирного банка Дилипа Рата, «денежные переводы - это крупный, устойчивый и антициклический источник внешнего финансирования для многих бедных стран» [Рата 2007: 15]. Так, в период кризиса 2008-2009 гг. объем учтенных переводов мигрантов в отличие от прямых иностранных инвестиций резко не сократился. По своему объему они превосходят официально полученную внешнюю помощь, сопоставимы с частной задолженностью и в настоящее время составляют примерно 2/3 от прямых иностранных инвестиций (таблица 3).

Таблица 3. Переводы мигрантов и другие источники внешнего финансирования развивающихся стран в 2006-2014 гг., млрд долларов США

\begin{tabular}{l|c|c|c|c}
\hline Год & $\begin{array}{c}\text { Полученные } \\
\text { денежные } \\
\text { переводы }\end{array}$ & $\begin{array}{c}\text { Прямые } \\
\text { инвестиции }\end{array}$ & $\begin{array}{c}\text { Негосударственная } \\
\text { задолженность и } \\
\text { портфельные инвестиции }\end{array}$ & $\begin{array}{c}\text { Официально } \\
\text { полученная } \\
\text { иностранная помощь }\end{array}$ \\
\hline 2006 & 228,6 & 361,3 & 227,9 & 105,4 \\
2007 & 279,5 & 480,2 & 333,8 & 104,9 \\
2008 & 324,8 & 540,9 & 121,7 & 122,8 \\
2009 & 302,9 & 385,2 & 196,8 & 120,6 \\
2010 & 335,7 & 528,8 & 309,4 & 129,1 \\
2011 & 377,9 & 630,5 & 249,8 & 134,7 \\
2012 & 400,7 & 582,7 & 375,9 & 126,9 \\
2013 & 416,2 & 671,3 & 421,7 & 135,1 \\
2014 & 431,1 & 661,8 & 442,6 & 135,2 \\
\hline
\end{tabular}

Для многих развивающихся стран денежные переводы являются важным источником иностранной валюты. Их объемы превосходят доходы от основных статей экспорта и покрывают значительную часть импорта. Так, в 2013 г. в Таджикистане объем денежных переводов превышал более чем в 11 раз объем валютных резервов страны, в Эквадоре - в 2,3 раза, в Египте - в 1,7 раза, в Пакистане - в 1,4 раза, в Армении и в Бангладеш - в 1,2 раза [World Bank 2013]. Даже в такой крупной развивающейся экономике, как экономика Индии, объем поступающих денежных переводов эквивалентен, по крайней мере, четверти всех валютных резервов. Во Вьетнаме объем переводов мигрантов приближается к выручке от экспорта нефтепродуктов, в Филиппинах переводы превышают 
выручку от экспорта электроники, в Пакистане экспорт хлопка приносит почти в 3 раза меньшую сумму, чем денежные переводы ${ }^{6}$.

Многочисленные исследования показывают, что денежные переводы мигрантов увеличивают уровень потребления, сбережений и инвестиций и снижают уровень бедности домохозяйств родственников и друзей мигрантов [Richard, Adams, Page 2005; UNCTAD 2011; Majeed 2015]. Так, результаты обследований домохозяйств (Армения, Молдавия, Таджикистан, Киргизия) показывают, что благодаря денежным переводам расширились потребление товаров длительного пользования, жилищное строительство, вложения в собственные земельные наделы. Быстро развивались розничная торговля и мелкий бизнес, использование современных средств коммуникации (мобильная связь, Интернет). При этом денежные переводы являются источником высоких расходов на выплату долга и проведение социально значимых мероприятий (свадьбы, похороны, юбилеи и др.) [National Statistic Service of Armenia 2007; Khakimov, Mahmadbekov 2009].

Домохозяйства, получающие денежную помощь из-за рубежа, больше вкладывают в получение их детьми образования и в охрану здоровья. Тем самым в стране происхождения трудовых мигрантов увеличивается накопленный человеческий капитал, что дает долговременный макроэкономический эффект. По мере роста доходов со временем расширяется круг потребностей получателей переводов и меняются стимулы к миграции. Многие мигранты из развивающихся стран сегодня не «бегут» от бедности, а стремятся обеспечить дальнейший рост благосостояния своих семей.

Ряд исследований говорит о том, что денежные переводы мигрантов даже на макроуровне повышают кредитоспособность и финансовую устойчивость страны, к тому же они могут способствовать включению финансовых институтов стран-получателей в мировую систему [Ratha, Mohapatra 2007]. Кроме того, на сегодняшний момент накоплен положительный опыт конвертации денежных переводов мигрантов в долгосрочные инвестиции (в том числе и связанные с производством общественных благ) в развивающихся странах, например, в Мексике и Индии. Однако в Африке из-за неразвитой институциональной среды и непрозрачности государственного финансирования подобные схемы пока работают плохо [Gupta, Pattillo, Wagh 2009].

Согласно результатам ежегодного опроса, проводимого Центральным банком Российской Федерации в 2012-2014 гг. среди лиц, осуществляющих денежные переводы за границу, почти 70\% денежных переводов направляется на удовлетворение текущих потребностей семьи, 12\% - на оплату услуг, $14-15 \%$ - на погашение кредитов [ЦБ РФ 2015].

Вместе с тем высказываются опасения, что денежные переводы могут замедлять экономический рост, в частности, вследствие уменьшения желания работать у родственников и друзей мигрантов, которые их получают. Но чаще этот тезис оспаривается, поскольку в исследованиях, на которые он опирается, не учитывался эффект накопления человеческого капитала. Возможно, замедление роста вызывает цепной процесс: более сильную миграцию и увеличение объема переводов из-за рубежа. Ряд исследователей

${ }^{6}$ Trade statistics for international business and Development. URL: http://www.trademap.org/Index.aspx (дата обращения: 18.01.16). 
утверждают, что денежные переводы увеличивают экономическое неравенство. Но эта точка зрения нуждается в более глубоком обосновании. Многие эксперты указывают на то, что при значительном объеме финансовых потоков местная валюта становится крепче, что снижает экспортный потенциал экономики страны, зависящей от переводов, влияет на занятость и вызывает рост инфляции. В определенной мере такие признаки обнаруживаются в некоторых странах СНГ, где местные товары, включая продукты питания, порой не могут конкурировать с дешевыми товарами из Китая и других стран Азии. Многие развивающиеся страны избирают «эмиграционную модель развития», ориентированную на экспорт рабочей силы как важную составляющую стратегии развития [Münz 2007].

\section{ПЕРЕВОДЫ МИГРАНТОВ В РОССИИ}

Первая оценка денежных переводов мигрантов из России и в Россию относится к 1994 г. Вплоть до начала 2000-х годов отток и приток денежных переводов различались незначительно и находились в интервале от 1 до 4 млрд долл. В 1994 и 2000 г. приток денежных переводов из-за рубежа даже превышал их отправление из России. Увеличение объемов переводов мигрантов началось с 2000-х годов. Согласно оценкам, для которых использовались статьи платежного баланса России, разработанного в ЦБ РФ по методологии ВОР6, за период с 2001 по 2014 г. объем денежных переводов за пределы России увеличился в почти в 36 раз, а в Россию - в 8 раз (рисунок 9) 7 . Особенно значительно вырос объем переводов мигрантов из России в страны СНГ - более чем в 60 раз против роста примерно в 20 раз в страны дальнего зарубежья. Благодаря столь бурной динамике Россия неожиданно быстро вышла на 2-е место в мире по объему отправленных денежных переводов после США, опередив Саудовскую Аравию и ведущие экономики развитого мира.

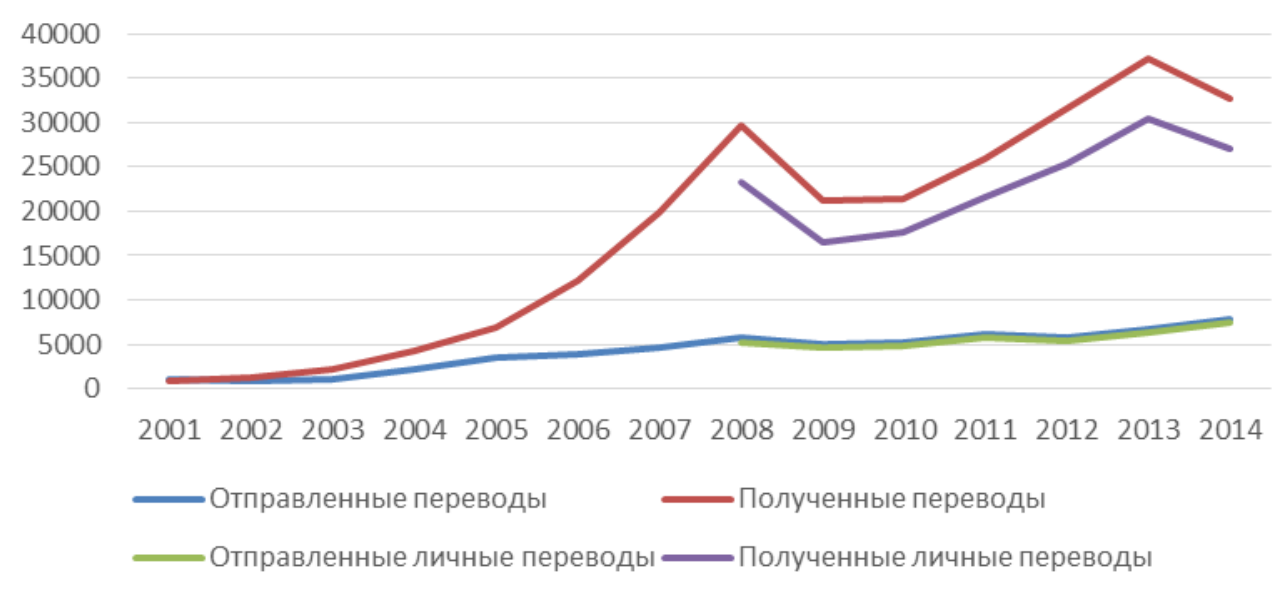

Рисунок 9. Денежные переводы мигрантов в России, 2001-2014, млрд долларов США Источник: [ЦБ РФ 2014b].

\footnotetext{
${ }^{7}$ В оценке использовался показатель «Оплата труда работников», а не «Чистая оплата труда». 
Среди причин столь бурного увеличения объемов переводов отметим следующие:

1. увеличение числа работающих на законных основаниях временных мигрантов, прежде всего из стран СНГ. Если в 2000 г. официально было учтено чуть более 200 тыс. трудовых мигрантов, то в 2014 г. было выдано более 3,7 млн разрешительных документов на работу;

2. рост заработков мигрантов, как, впрочем, и всего занятого работающего населения России. Реальная заработная плата за период 2001-2013 гг. выросла более чем в 3,5 раза;

3. активная переориентация мигрантов с неформальных на формальные каналы переводов денежных средств на родину как результат развития финансовых институтов и низкой стоимости денежных переводов из России в страны СНГ. Для денежных переводов в России нехарактерна проблема высокой стоимости операции, поскольку еще в 2000-х годах на рынке срочных денежных переводов без открытия счета заметно выросло число обслуживающих их операторов, включая услугу по электронным переводам денежных средств «Киберденьги» Почты России. В России также обеспечивалось действие Закона «О защите конкуренции на рынке банковских услуг». Уже в 2007 г. комиссия по переводам в страны СНГ находилась в интервале от 1,5 до 3\%, и была одной из самых низких в мире. В 2014 г., по оценке Банка России, средневзвешенный размер комиссии за трансграничные переводы физических лиц составлял $1,4 \%$ от суммы операции [ЦБ РФ 2014b] и, по нашим оценкам, был самым низким среди стран мира;

4. улучшение полноты и качества сбора соответствующей информации, в первую очередь о трудовых мигрантах и финансовых операциях. На это направлена деятельность Центрального банка и ФМС России.

В результате кризиса 2008 г. денежные переводы в 2009 г. сократились практически на треть. Но уже в 2012 г. докризисный уровень был превзойден, а в 2013 г. достигнут абсолютный максимум отправленных денежных переводов из России. Из-за начавшихся кризисных явлений в 2014 г. объем денежных переводов из России сократился примерно на $12 \%$ по отношению к предыдущему году, страна отодвинулась на 3-е место в мире, пропустив вперед Саудовскую Аравию. В 2015 г. из-за спада в экономике, продолжающегося обесценивания рубля и вступивших в силу ограничений на использование труда мигрантов, как будет показано ниже, наблюдается дальнейшее сокращение величины переводов. При этом каких-то резких колебаний и снижения объемов переводов, поступающих в Россию, не наблюдается.

Как отмечалось ранее, в конце 2000-х годов Центральный банк России перешел к показателю «личные переводы» как индикатору переводов мигрантов. Приведенные на рисунке 9 и в таблице 4 оценки ниже тех, которые дает Всемирный банк, поскольку, как уже отмечалось, при расчете «Личных переводов» используется показатель оплаты труда за вычетом налогов, социальных вычетов и расходов, связанных с пребыванием, т.е. «чистая оплата труда». По данным ЦБ РФ за период с 2010 по 2014 г. из России было отправлено почти 122 млрд долл., в том числе в страны СНГ - 96 млрд, в страны дальнего зарубежья - 26 млрд. Уменьшение объемов отправленных денежных переводов связанно именно со странами СНГ. Обратный поток составил почти 30 млрд долл., его большая часть (22 млрд) получена из дальнего зарубежья. 
Таблица 4. Личные переводы из России и в Россию, млн долларов США

\begin{tabular}{l|r|r|r|r|r}
\hline & \multicolumn{1}{c}{2010} & 2011 & \multicolumn{1}{c}{2012} & \multicolumn{1}{c}{2013} & \multicolumn{1}{c}{2014} \\
\hline Полученные: всего & 4810 & 5672 & 5377 & 6397 & 7450 \\
из СНГ & 908 & 1353 & 1344 & 2051 & 2215 \\
из дальнего зарубежья & 3902 & 4319 & 4033 & 4346 & 5234 \\
Выплаченные: всего & 17648 & 21495 & 25356 & 30406 & 27016 \\
в СНГ & 13525 & 16526 & 20110 & 24786 & 21400 \\
в дальнее зарубежье & 4123 & 4969 & 5246 & 5619 & 5616 \\
\hline
\end{tabular}

Источник: [ЦБ РФ 2014а].

Главный получатель личных переводов мигрантов из России, по данным ЦБ РФ, Узбекистан (рисунок 10). На эту страну приходится почти треть всех полученных странами СНГ переводов с 2011 по 2014 г. Украина с Таджикистаном по этому показателю занимают 2-е и 3-е места. В 2014 г. объем отправленных в Узбекистан денежных переводов сократился более чем на 25\%. Это больше, чем для других стран СНГ. Общее уменьшение объемов отправленных денежных переводов из России в 2014 г. объясняется на 61\% их сокращением в Узбекистане, на 27\% - в Украине и только на 12\% - в остальных странах.

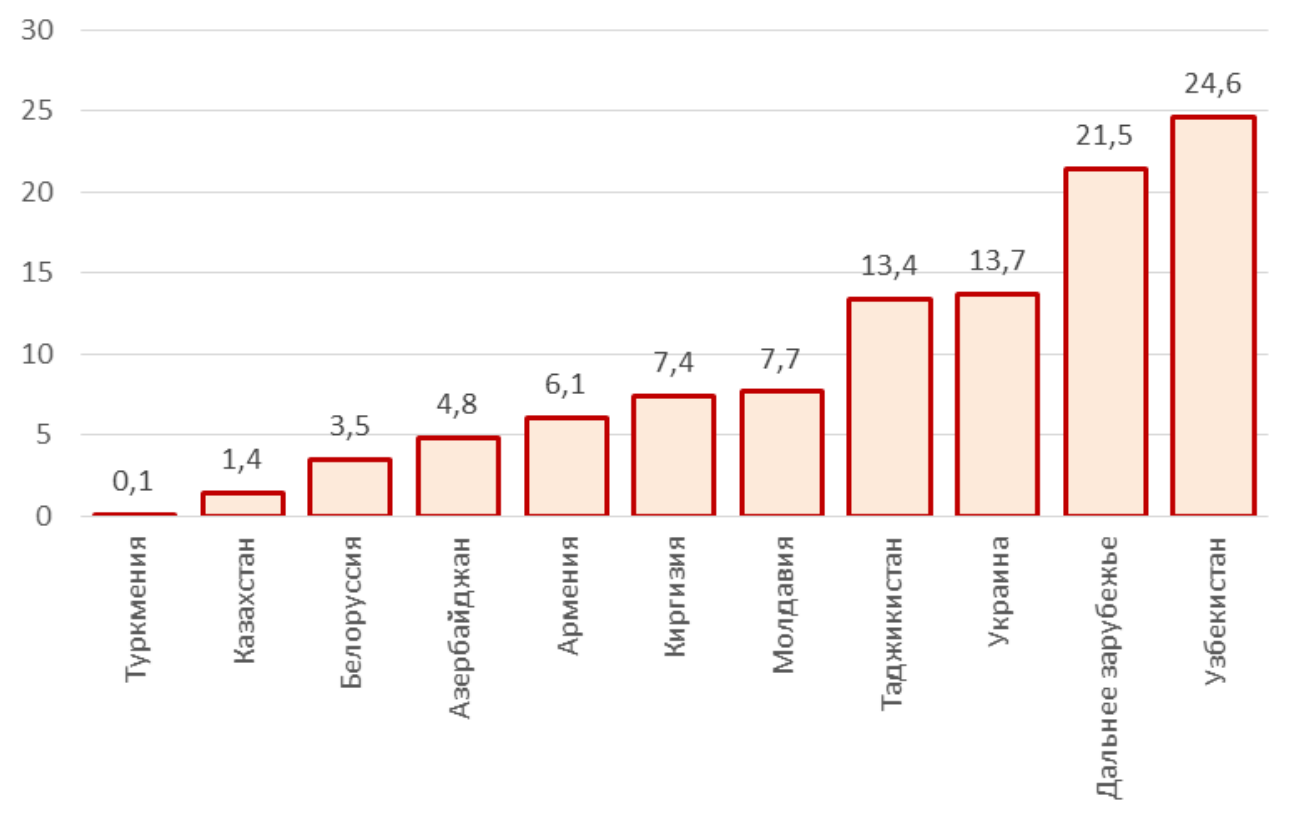

Рисунок 10. Личные переводы из России по странам-получателям, 2011-2014, млрд долларов США

Источник: [ЦБ РФ 2014b].

Оценки объемов личных переводов из России в страны СНГ, выполненные для первых двух кварталов 2015 г., свидетельствуют об их заметном уменьшении (таблица 5). В первом квартале 2015 г. объем трансфертов был на 45,5\% меньше, чем в первом квартале 2014 г. Во втором квартале масштабы сокращения уменьшились на 3 п.п. до 42,5\%. Подобная негативная динамика определялась, в первую очередь, сокращением личных переводов из России в Узбекистан и Таджикистан, на которые в 2014 г. приходилось более $44 \%$ от всего денежного потока в страны СНГ. 


\section{Таблица 5. Личные переводы из России в страны СНГ в I и П кварталах 2014-2015, млн долларов США}

\begin{tabular}{l|r|r|r|r|r|r}
\hline & I квартал & II квартал & I квартал & II квартал & \multicolumn{2}{|c}{ Прирост за 2014-2015 гг., \% } \\
\cline { 6 - 8 } & 2014 г. & 2014 г. & 2015 г. & 2015 г. & I квартал & II квартал \\
\hline Страны СНГ & 4542 & 5749 & 2475 & 3303 & $-45,5$ & $-42,5$ \\
Азербайджан & 310 & 360 & 155 & 231 & $-50,0$ & $-35,8$ \\
Армения & 347 & 434 & 207 & 320 & $-40,3$ & $-26,3$ \\
Белоруссия & 221 & 257 & 134 & 137 & $-39,4$ & $-46,7$ \\
Казахстан & 104 & 116 & 56 & 94 & $-46,2$ & $-19,0$ \\
Киргизия & 459 & 622 & 284 & 436 & $-38,1$ & $-29,9$ \\
Молдавия & 388 & 503 & 190 & 238 & $-51,0$ & $-52,7$ \\
Таджикистан & 743 & 986 & 434 & 528 & $-41,6$ & $-46,5$ \\
Туркмения & 8 & 9 & 3 & 5 & $-62,5$ & $-44,4$ \\
Узбекистан & 1201 & 1645 & 634 & 850 & $-47,2$ & $-48,3$ \\
Украина & 761 & 817 & 377 & 466 & $-50,5$ & $-43,0$ \\
\hline
\end{tabular}

Источник: [ЦБ РФ 2014b].

Подобные изменения связаны, во-первых, с падением курса рубля. Обменный курс рубля в I квартале 2014 г. составлял 35,69 руб. за доллар США, во II квартале - 33,63 руб. В 2015 г. к концу соответствующих периодов он вырос более чем в 1,6 раза и стал равен 58,46 и 55,52 руб. за доллар. Во-вторых, на уменьшение объемов денежных переводов повлияло и сокращение потока трудовых мигрантов в Россию. Число незаконных трудовых мигрантов сократилось более чем на 900 тыс. человек и составило по оценкам ФМС в 2015 г. 2,7 млн человек вместо 3,6 млн в 2014 г. Также сократилось и число иностранных граждан, осуществляющих трудовую деятельность в России на законных основаниях. По нашим оценкам, основанным на статистике ФМС РФ, общее количество разрешительных документов для осуществления трудовой деятельности, выданных иностранным гражданам из стран с безвизовым пересечением границы (с учетом разрешений на работу высококвалифицированным специалистам), сократилось за первые два квартала 2015 г. по сравнению с аналогичным периодом 2014 г. более чем на 35\%. Эта оценка не учитывает трудовых мигрантов из Армении, которые после присоединения этой страны к Таможенному союзу могут осуществлять трудовую деятельность в России без получения разрешительных документов.

Уменьшение числа трудовых мигрантов обусловлено экономической рецессией. Сократился спрос на иностранную рабочую силу. Кроме того, уменьшение числа мигрантов в определенной мере является и результатом действия мер, введенных в 2012-2014 гг. и направленных на усиление ответственности за нарушение миграционного законодательства. Согласно оценкам ФМС РФ, к концу мая 2015 г. почти 1,4 млн иностранных граждан был запрещен въезд на территорию России за нарушение в прошлом миграционного законодательства РФ. К концу сентября их число увеличилось еще примерно на 300 тыс. человек. Большинство из тех, кому въезд на территорию России закрыт на срок от 3 до 10 лет, составляют граждане Узбекистана и Таджикистана. Необходимо отметить, что в течение первых двух кварталов 2015 г. среди стран с безвизовым режимом пересечения границы наибольшее сокращение выданных разрешительных документов для осуществления трудовой деятельности отмечается у граждан Киргизии (почти на 80\%), что связано с новыми «миграционными ожиданиями» от присоединения этой страны к ЕАЭС. Далее идет Украина, гражданам которой было 
выдано почти на 65\% разрешительных документов меньше, чем за тот же период 2014 г. Очевидно, что часть бывших трудовых мигрантов могла сменить свой миграционный статус (получить временное убежище, разрешение на временное проживание и др.) из-за трагических событий на их родине.

$$
* * *
$$

Роль денежных переводов в экономическом развитии многих бедных стран Азии (включая страны СНГ), Африки и Латинской Америки, значительна. В период с 2008 по 2014 г., несмотря на мировой финансовый кризис и исчерпание эффекта низкой базы, поток трансфертов продолжал увеличиваться. Трансферты мигрантов вносят заметный вклад в экономику слаборазвитых стран, существенно влияя на объем ВВП, в некоторых из них они существенно превышают по величине иностранные инвестиции и помощь. Денежные переводы способствуют поддержанию стабильности экономического развития, они более устойчивы, чем другие финансовые потоки из-за рубежа, поскольку не зависят от мировой внешнеполитической конъюнктуры. Денежные переводы мигрантов увеличивают уровень потребления, сбережений и инвестиций и снижают уровень бедности домохозяйств родственников и друзей мигрантов.

Россия с середины 2000-х годов является одним из главных источников происхождения трансфертов мигрантов. В последние годы страна делит по их объему 2-3е место с Саудовской Аравией (на 1-м месте - США). География денежных переводов из России в точности отражает систему трудовой миграции, главным источником которой являются страны СНГ. В 2013 г. трансферты мигрантов из России достигли своего пика (более 37 млрд долл.). В последующий период началось уменьшение их объемов. Особенно значительным это уменьшение было в первой половине 2015 г. По сравнению с соответствующим периодом предыдущего года эта убыль составила почти 45\% или 4,5 млрд долларов США. Главными причинами уменьшения потоков стали экономическая рецессия, сопровождающаяся значительным падением обменного курса рубля, сокращение спроса на иностранную рабочую силу и последствия ужесточения наказаний за нарушение миграционного законодательства в форме запрета въезда на территорию России.

Уменьшение объема денежных переводов окажет влияние не только на экономическую обстановку, но и на общественно-политические настроения населения в тех странах, где денежные переводы имеют большое значение для поддержания достигнутого уровня благосостояния. Речь идет в первую очередь об Узбекистане, Таджикистане, Молдавии, в меньшей степени - об Украине.

Несмотря на все проблемы глобальной политической ситуации и неявные перспективы мирового экономического роста, денежные переводы мигрантов продолжат расти в силу разных причин: интенсификации мирохозяйственных связей, увеличения миграционных потоков в условиях не уменьшающихся демографических и экономических различий между странами, облегчения и удешевления процедуры денежных транзакций и др. На современном этапе важно рассматривать денежные переводы мигрантов не только как самостоятельное явление, но и как инструмент развития стран-получателей. 


\section{ЛИТЕРАТУРА}

Глущенко Г.И. (2004). Денежные переводы - фактор инновационного развития мировой финансовой инфраструктуры // Вопросы статистики. №8: 36-48.

Глущенко Г.И. (2005). Денежные переводы международных трудовых мигрантов: характеристики и детерминанты // Вопросы статистики. №3: 38-50.

Денисенко М.Б., О.А. Хараева (2008). Переводы гастарбайтеров: на перекрестке между миграцией и экономикой // Демоскоп-Weekly. №339-340. URL: http://www.demoscope.ru/weekly/2008/0339/tema01.php (дата обращения: 18.01.2016).

Рата Д. (2007). Денежные переводы мигрантов: роль для экономического развития // Beyond Transition. №16: 15-17.

ЦБ РФ (2014a). Методологический комментарий и информационная база. URL: http://www.cbr.ru/statistics/CrossBorder/method-komm_pr.pdf (дата обращения: 18.01.2016).

ЦБ РФ (2014b). Трансграничные переводы физических лиц в 2014 году. URL: http://www.cbr.ru/statistics/CrossBorder/CrossBorder_2014.pdf (дата обращения: 18.01.2016).

ЦБ РФ (2015). Департамент статистики. Результаты анкетирования физических лиц, осуществляющих трансграничные денежные переводы. URL: http://www.cbr.ru/statistics/CrossBorder/results_trans.pdf (дата обращения: 18.01.2016).

Catrinecsu N., L. Miguel, P. Matloob, B. Quillin (2009). Remittances, Institutions and Economic growth // World Development. 37(1):81-92.

Chami R., A. Barajas, T. Cosimano, C. Fullenkamp, M. Gapen, P. Montiel (2008). Macroeconomic Consequences of Remittances.Washington D.C.: IMF.

European Parliament (2015). Irregular migration in EU: Fact and Figures Briefing.

Gupta S., C.A. Pattillo, S. Wagh (2009). Effect of remittances on poverty and financial development in Sub-Saharan Africa // World Development. 37(1):104-115.

IMF (1993). Balance of Payments. Manual, Fifth Edition (BOP5).

IMF (2009). Balance of Payments and International Investment Position Manual (BPM6). URL: https://www.imf.org/external/.../bopman6.htm (дата обращения: 18.01.2016).

IMF, Eurostat, OECD, World Bank (2009). International transactions in Remittances. Guide for Compilers and Users. Washington D.C.: IMF.

Khakimov P., Mahmadbekov M. (2009). Economic dynamics of labor migrant remittances in Tajikistan. Dushanbe: IOM.

Majeed M.T. (2015). Poverty Effects of Remittances: a Comparative Analysis // Journal of International Development. 27(1):1-14.

Münz R. (2007). Remittances: Is there a Coherent View on the Development Impact? // G8 Outreach Meeting on Remittances. Berlin.

National Statistic Service of Armenia (2007). Report Labour migration of Armenia. Yerevan.

Ratha D., S. Mohapatra (2007). Increasing the macroeconomic impact of remittances on development. World Bank.

Richard H., J. Adams, J. Page (2005). Do International Migration and Remittances Reduce Poverty in Developing Countries? // World Development. 33(10):1645-1669 
Shelburne R.C., J. Palacin (2007). Remittances in the CIS: Their Economic Implications and a New Estimation Procedure // UNECE DISCUSSION PAPERS SERIES. № 5.

UN (2014). Open Working Group proposal for Sustainable Development Goals. URL: https://sustainabledevelopment.un.org/content/documents/1579SDGs\%20Proposal.pdf (дата обращения: 18.01.2016).

UNCTAD (2011). Impact of remittances on poverty in developing countries. United Nations.

UNHCR (2015). Mid-year trends, June 2015. URL:

http://www.unhcr.org/pages/49c3646c4d6.html (дата обращения: 18.01.2016).

World Bank (2006). Migration and Remittances / Edited by A. Mansoor and B. Quillin. Washington D.C.

World Bank (2013). Migration and Remittance: Recent Trends and Outlook, 2013-2016 // Migration and Development Brief 21.

World Bank (2015). Migration and Remittances: Recent Developments and Outlook // Migration and Development Brief 25.

World Bank Data (2016). URL: http://data.worldbank.org (дата обращения: 18.01.16).

World Bank Group (2015). Migration and Remittances. Factbook 2016. Third Edition. 


\title{
RECENT TRENDS IN REMITTANCES: RUSSIA AND THE WORLD* \\ MIKHAIL DENISENKO, VLADIMIR A. KOZLOV, ASIA FATTAKHOVA
}

Mikhail Denisenko. Institute of Demography, National ReSEARch University Higher School of Economics, Russia. E-MAIL: mdenissenko@hse.ru

Vladimir Kozlov. Institute of Demography, National Research University Higher School of Economics, Russia. Asia Fattakhova. Institute of Demography, National Research University Higher School of Economics, Russia.

DATE RECEIVED: March 2014.

\begin{abstract}
The article presents a detailed description of global remittance trends and the factors influencing them. The authors focus on recent changes among leading countries in the sending and receiving of remittances and analyze the reasons for these changes. Moreover, the article sheds light on the role of remittances in the socio-economic development of poor countries. The article begins with an analysis of the sources of remittances, as there have been recent conceptual changes in the methods of calculating these flows. The authors pay special attention to money remittances in Russia and the factors of discrepancies between remittances as calculated by Central Bank and World Bank methodologies.
\end{abstract}

Key words: remittances, migration, remittances of migrants and development.

\footnotetext{
* THIS ARTICLE IS AN OUTPUT OF A RESEARCH PROJECT "MECHANISMS FOR ATTRACTION AND INVOLVEMENT THE INTERNATIONAL WORKERS ON THE RUSSIAN LABOUR MARKET (2015 T3-114)" IMPLEMENTED AS PART OF THE BASIC Research Program at the National Research University Higher SchoOl of Economics (HSE).
}

\section{REFERENCES}

Catrinecsu N., L. Miguel, P. Matloob, B. Quillin (2009). Remittances, Institutions and Economic growth // World Development. 37(1):81-92.

CB RF (2014a). Metodologicheskij kommentarij i informatsionnaya baza. [Methodology and information base] URL: http://www.cbr.ru/statistics/CrossBorder/method-komm_pr.pdf (accessed: 18.01.2016).

CB RF (2014b). Metodologicheskij kommentarij i informatsionnaya baza. [Cross-border transfers of individuals in 2014]. URL: http://www.cbr.ru/statistics/CrossBorder/CrossBorder_2014.pdf (accessed: 18.01.2016).

CB RF (2015). Departament statistiki. Rezul'taty anketirovaniya fizicheskikh lits, osushhestvlyayushhikh transgranichnye denezhnye perevody. [Department of Statistics. The results of the survey of individuals engaged in cross-border remittances]. URL: http://www.cbr.ru/statistics/CrossBorder/results_trans.pdf (accessed: 18.01.2016).

Chami R., A. Barajas, T. Cosimano, C. Fullenkamp, M. Gapen, P. Montiel (2008). Macroeconomic Consequences of Remittances. Washington D.C.: IMF.

Denisenko M.B., O.A. Kharaeva (2008). Perevody gastarbajterov: na perekrestke mezhdu migratsiej i ehkonomikoj [Migrant Remittances:at the intersection between migration and the economy] // Demoskop-Weekly №339-340. URL:

http://www.demoscope.ru/weekly/2008/0339/tema01.php (accessed: 18.01.2016).

European Parliament (2015). Irregular migration in EU: Fact and Figures Briefing. 
Glushhenko G.I. (2004). Denezhnye perevody - faktor innovatsionnogo razvitiya mirovoj finansovoj infrastruktury [Remittances - the factor of innovative development of the world's financial infrastructure] // Voprosy statistiki. [Statistical issues] № 8: 36-48.

Glushhenko G.I. (2005). Denezhnye perevody mezhdunarodnykh trudovykh migrantov: kharakteristiki i determinant [Migrant Remittances:characteristics and determinants] // Voprosy statistiki. [Statistical issues] №3:38-50.

Gupta S., C. A. Pattillo, S. Wagh (2009). Effect of remittances on poverty and financial development in Sub-Saharan Africa // World Development. 37(1):104-115.

IMF (1993). Balance of Payments. Manual, Fifth Edition (BOP5).

IMF (2009). Balance of Payments and International Investment Position Manual (BPM6). URL: https://www.imf.org/external/.../bopman6.htm (accessed: 18.01.2016).

IMF, Eurostat, OECD, World Bank (2009). International transactions in Remittances. Guide for Compilers and Users. Washington D.C.: IMF.

Khakimov P., M. Mahmadbekov (2009). Economic dynamics of labor migrant remittances in Tajikistan. Dushanbe: IOM.

Majeed M.T. (2015). Poverty Effects of Remittances: a Comparative Analysis // Journal of International Development. 27(1):1-14.

Münz R. (2007). Remittances: Is there a Coherent View on the Development Impact? // G8 Outreach Meeting on Remittances. Berlin.

National Statistic Service of Armenia (2007). Report Labour migration of Armenia. Yerevan.

Rata D. (2007). Denezhnye perevody migrantov: rol' dlya ehkonomicheskogo razvitiya [Remittances: role in economic development] // Beyond Transition. №16: 15-17.

Ratha, D., S. Mohapatra (2007). Increasing the macroeconomic impact of remittances on development. World Bank.

Richard H., J. Adams, J. Page (2005). Do International Migration and Remittances Reduce Poverty in Developing Countries? // World Development. 33(10).

Shelburne R.C., J. Palacin (2007). Remittances in the CIS: Their Economic Implications and a New Estimation Procedure // UNECE DISCUSSION PAPERS SERIES. №5.

UN (2014). Open Working Group proposal for Sustainable Development Goals. URL: https://sustainabledevelopment.un.org/content/documents/1579SDGs\%20Proposal.pdf (accessed: 18.01.2016).

UNCTAD (2011). Impact of remittances on poverty in developing countries. United Nations.

UNHCR (2015). Mid-year trends, June 2015. URL:

http://www.unhcr.org/pages/49c3646c4d6.html (accessed: 18.01.2016).

World Bank (2006). Migration and Remittances // Edited by A. Mansoor and B. Quillin.

World Bank (2013). Migration and Remittance: Recent Trends and Outlook, 2013-2016 // Migration and Development Brief 21.

World Bank (2015). Migration and Remittances: Recent Developments and Outlook // Migration and Development Brief 25.

World Bank Data (2016). URL: http://data.worldbank.org/ (accessed: 18.01.2016).

World Bank Group (2015). Migration and Remittances. Factbook 2016. Third Edition. 